\title{
Critical analysis of the Brazilian national standard for concrete permeable pavement
}

\author{
M. Marchioni ${ }^{1}$, G. Becciu ${ }^{1} \&$ C. Silva ${ }^{2}$ \\ ${ }^{1}$ Department of Civil and Environmental Engineering, \\ Politecnico di Milano, Italy \\ ${ }^{2}$ Associação Brasileira de Cimento Portland (ABCP), Brazil
}

\begin{abstract}
The use of permeable pavement in Brazil has increased significantly in recent years, after being considered and encouraged in town Urban Drainage Masterplans and legislation. Unfortunately pathologies and poor performance are often observed. As part of sustainable urban drainage systems (SUDs) the main goal with a permeable pavement is to reduce the volume and also to increase the quality of stormwater runoff, but incorrect design and construction and/or lack of proper maintenance could lead to not meeting these goals. It then becomes necessary to develop the standards of the design, construction and maintenance of permeable pavements. In the paper the yet to be published Brazilian national standard for concrete permeable pavement is analyzed.

Keywords: permeable pavement, standardization, standard, SUDs, sustainable drainage.
\end{abstract}

\section{Introduction}

Following a worldwide trend, sustainable urban drainage systems (SUDs) strategies have been encouraged in Brazil in the last few years. These strategies are considered in most of the town regulations and Urban Drainage Masterplans. One of the most important is the use of permeable pavements. In most cases, however, a lack of knowledge is still observed in all the application steps, from design to evaluation. This entails a serious risk of improper working or, at least, a significant reduction of efficiency of this kind of stormwater control solutions. The development of a national standard comes to fulfill this gap. 
The main goals of this standard is not only to be used as an official reference at the legal level, but also to provide a guideline to designers, developers and public administrations. The standard covers terms and definitions, concrete surface course types, cross section types, requirements, construction, maintenance, test method for evaluation and a recommendation guideline for design.

Although the attendance of its recommendations is voluntary, in case of developments involving public agencies it becomes mandatory. So, a national standard has more strength than simple guidelines and is usually more effective in stimulating the growth of good practices on the field.

\section{Permeable pavement standards}

Some standards of permeable pavements in other countries were considered for reference. In the European Committee for Standardization (CEN) there aren't specific standards for permeable pavements. The British Standard Institution (BSI) however is available, the "BS 7533-13:2009. Pavements constructed with clay, natural stone or concrete pavers. Guide for the design of permeable pavements constructed with concrete paving blocks and flags, natural stone slabs and setts and clay pavers" (BSI [1]) which was used as reference for ABNT [2]. Besides the mechanical and hydraulic design criteria, the standard gives requirements for all pavement layers considering only the permeable interlocking concrete pavements.

On ASTM International (ASTM) there is a test method to measure the surface infiltration for permeable pavement that was used as reference on ABNT [2] and also standards that refer particularly to pervious concrete:

- $\quad$ ASTM C1688/C1688M-14a Standard Test Method for Density and Void Content of Freshly Mixed Pervious Concrete

- $\quad$ ASTM C1754/C1754M-12 Standard Test Method for Density and Void Content of Hardened Pervious Concrete

- $\quad$ ASTM C1747/C1747M-13 Standard Test Method for Determining Potential Resistance to Degradation of Pervious Concrete by Impact and Abrasion

- $\quad$ ASTM C1701/C1701M-09 Standard Test Method for Infiltration Rate of In Place Pervious Concrete

The American Concrete Institute (ACI) also brings specific documents for pervious concrete:

- 522.1-13 Specification for Pervious Concrete Pavement

- $\quad$ 522R-10 Report on Pervious Concrete (Reapproved 2011)

- $\quad$ 522.1M-13 Metric Specification for Pervious Concrete Pavement

As seen above, normally it is preferred to have different standards that cover specifics requirements and test methods, rather than general standards referring to all issues of permeable pavements.

\section{Terms and definitions}

On terms and definitions the most important item is the definition of the pavement itself: a common mistake regarding permeable pavement is to apply a permeable 
surface over an impermeable/conventional structure. As it is possible to observe in Pagotto et al. [3] (Table 1), installing a pervious surface over a conventional base has no effect on runoff coefficient reduction, basically the main goal of permeable pavements.

Table 1: Comparison among wearing course applied on highway (Pagotto et al. [3]).

\begin{tabular}{|l|c|c|}
\hline & $\begin{array}{c}\text { Conventional } \\
(1995-1996)\end{array}$ & $\begin{array}{c}\text { Porous Asphalt* } \\
(1997-1998)\end{array}$ \\
\hline Number of rain events & 125 & 162 \\
\hline Total depth of rainwater $(\mathrm{mm})$ & 698 & 796 \\
\hline Total duration of events with runoff $(\mathrm{h})$ & 646 & 774 \\
\hline Flow volume $\left(\mathrm{m}^{3} / \mathrm{ha}\right)$ & 5840 & 7825 \\
\hline Total duration of flow (h) & 1108 & 1457 \\
\hline Mean of runoff coefficient & 0.84 & 0.98 \\
\hline Mean of response time (h:min) & $1: 15$ & $2: 30$ \\
\hline
\end{tabular}

*maintaining the same conventional structure

In ABNT [2], pavement is defined as a structure that is able at the same time to resist and support vehicular loads and shear stresses and to improve surface course features regarding safety and comfort. The permeable pavement must comply with these requirements, while at the same time allowing the reduction of surface water impoundment and flow through infiltration and temporary storage. In respect of simple draining layers, permeable pavements should be able to also reduce runoff and to provide hydrograph attenuation. Hence the definition makes essential the presence of a permeable base to be considered a permeable pavement.

\section{Surface course types}

On concrete permeable pavement the surface course can be divided in two main types: modulated and monolithic. It is important to make such division since they will behave differently, although the requirements for infiltration must remain the same. The modulated can be interlocking concrete pavement or concrete slabs. Permeable interlocking concrete pavement allows water infiltration through enlarged joints or open spaces of solid units or through pervious concrete units. Concrete slabs provide water infiltration though the porous on the pervious concrete and are recommended for pedestrian traffic only. The monolithic type is made with pervious concrete cast in place.

\section{Type of cross section}

Permeable pavement can present three main types of cross section regarding infiltration: full, partial or no infiltration depending on subgrade features and contamination risk. On full infiltration all water goes to the subgrade, on partial 
infiltration, part of the water goes to the subgrade and part through drainage pipes and on no infiltration all the water infiltrates through drainage pipes (Figure 1).
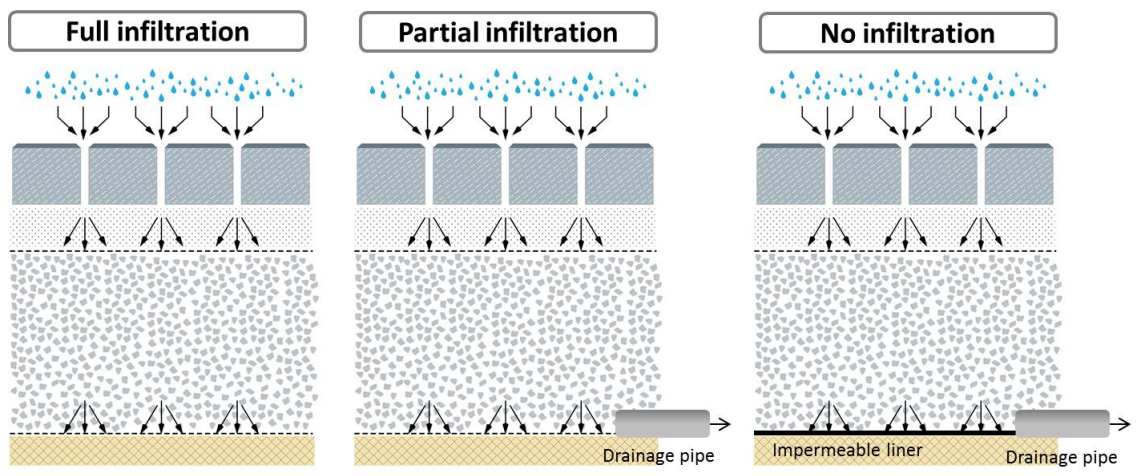

Figure 1: Type of cross section according to water infiltration (ABCP collection).

The ABNT [2] brings a reference attachment to help choose the infiltration type mention in section 0 , although the designer is free to use the methodology that is considered the most suitable.

\section{Requirements}

\subsection{General}

Design should follow mechanical and hydraulic requirements and take in consideration the location and use of the site. ABNT [2] brings a few items that must be addressed on the design:

- $\quad$ implementation, type of use and interferences on pavement;

- $\quad$ load types and magnitude;

- $\quad$ subgrade load support;

- $\quad$ subgrade infiltration rate;

- $\quad$ soil behavior on saturated conditions when using total or partial infiltration;

- water table level, which is recommend to be at least $0.60 \mathrm{~m}$ below the pavement's structure;

- contribution area cannot exceed five times the pavement area;

- $\quad$ minimum slope of $0.5 \%$ and maximum slope of $5 \%$, for the contribution area maximum slope of $20 \%$;

- when using precast concrete on surface course minimum mechanical resistance; bulk density when adopting pervious concrete cast in place;

- $\quad$ transversal and longitudinal joints detailing when using pervious concrete cast in place;

- water table contamination risk assessment. 
Since designers in Brazil are not completely familiar with permeable pavement this item can be used as an initial reference without demanding a particular design method, which should be the choice of the designer. However the ABNT [2] also brings a suggestion of design method describe in section 10.

\subsection{Materials for base and subbase}

The conventional materials used on pavements are normally not suitable on permeable pavement, where the base/subbase should function as a reservoir allowing water infiltration and retention. To guarantee that the ABNT [2] recommends a void content of at least $32 \%$ and less than $2 \%$ of material finer than the $0.075 \mathrm{~mm}$ sieve (Table 2). It also recommends a grading size that would comprise those requirements (Table 3).

Table 2: Requirements for granular materials for base/subbase, bedding layers and joint material.

\begin{tabular}{|l|c|c|}
\hline Feature & Method & Requirement \\
\hline "Los Angeles" abrasion & ABNT NBR NM 51 & $\geq 40$ \\
\hline Void content & ABNT NBR NM 45 & $\geq 80 \%$ \\
\hline $\begin{array}{l}\text { California bearing ratio } \\
\text { (CBR) for base/subbase }\end{array}$ & ABNT NBR 9895 & $\leq 2 \%$ \\
\hline $\begin{array}{l}\text { Passing material on } \\
0.075 \text { mm sieve }\end{array}$ & ABNT NBR NM 46 & $9.5 \mathrm{~mm}$ \\
\hline $\begin{array}{l}\text { Bedding layer maximum } \\
\text { aggregate size }\end{array}$ & ABNT NBR 7212 & \multicolumn{1}{|c|}{$\begin{array}{c}\leq 1 / 3 \text { of the smallest joint } \\
\text { or open space width }\end{array}$} \\
\hline $\begin{array}{l}\text { Joint material maximum } \\
\text { aggregate size }\end{array}$ & ABNT NBR 7212 \\
\hline
\end{tabular}

Table 3: Grading size distribution for base/subbase.

\begin{tabular}{|c|c|c|}
\hline \multirow{2}{*}{ Sieve size } & \multicolumn{2}{|c|}{ Cumulative percent retained in mass (\%) } \\
\cline { 2 - 3 } & Subbase & Base \\
\hline $75 \mathrm{~mm}$ & 0 & - \\
\hline $63 \mathrm{~mm}$ & 0 a 10 & - \\
\hline $50 \mathrm{~mm}$ & 30 a 65 & - \\
\hline $37.5 \mathrm{~mm}$ & 85 a 100 & 0 \\
\hline $25 \mathrm{~mm}$ & $90 \mathrm{a} 100$ & 0 a 5 \\
\hline $19 \mathrm{~mm}$ & $95 \mathrm{a} 100$ & 0 a 35 \\
\hline $12.5 \mathrm{~mm}$ & - & $40 \mathrm{a} 75$ \\
\hline $4.75 \mathrm{~mm}$ & - & $90 \mathrm{a} 100$ \\
\hline $2.36 \mathrm{~mm}$ & - & $95 \mathrm{a} 100$ \\
\hline
\end{tabular}




\subsection{Bedding layer and jointing material}

Permeable interlocking concrete pavement requires a bedding layer that serves as a smooth surface to the paving units and material to fill the joints, when it is the case. On regular interlocking concrete pavement sand is normally used but in permeable pavement a material with low fines content should be used that could allow fast water infiltration. The ABNT [2] recommends a grading size distribution according Table 4. It is also mentioned that the bedding layer should be uniform and constant and its length should be referred in project, being recommended between $20 \mathrm{~mm}$ and $60 \mathrm{~mm}$ before compaction with $\pm 5 \mathrm{~mm}$ variation. The jointing material should fill the spaces until $5 \mathrm{~mm}$ below the surface. The use of sand or stone dust is a common mistake that could block the water infiltration compromising the pavement performance from start.

Table 4: Grading size distribution recommendation for bedding layers and joint material.

\begin{tabular}{|c|c|}
\hline Sieve size & Cumulative percent retained in mass (\%) \\
\hline $12.5 \mathrm{~mm}$ & 0 \\
\hline $9.5 \mathrm{~mm}$ & $0 \mathrm{a} 15$ \\
\hline $4.75 \mathrm{~mm}$ & $70 \mathrm{a} 90$ \\
\hline $2.36 \mathrm{~mm}$ & $90 \mathrm{a} 100$ \\
\hline $1.16 \mathrm{~mm}$ & $95 \mathrm{a} 100$ \\
\hline
\end{tabular}

\subsection{Surface course}

\subsubsection{Mechanical requirements}

Table 5 mentions the mechanical resistance requirements for the surface course. On paving units of solid concrete the requirements are the same as for the conventional non permeable pavement according to ABNT NBR 9781. On paving units with pervious concrete the requirement is lower than the conventional one, maintaining the same test method. Due to the porous content, the results on mechanical resistance on pervious concrete present a high variance and thus it would be advised to adopt another feature as a control requirement. On pervious concrete cast in place it is advised to use density while on pervious concrete paving units could also use density or abrasion as there is a test method describe on the ABNT NBR 9781. Particularly in the case of the paving unit, adopting a lower resistance could bring confusion with the conventional concrete by bringing the misleading perception that the pervious concrete requires less strength.

The paving units or slabs, when delivered in less than 28 days, should present at least $80 \%$ of the resistance specified in the project. The pervious concrete cast in place should comprise with the ABNT NBR 7212 - Execução de concreto dosado em central - Procedimento and present the strength gain curve. 
Table 5: Mechanical resistance and minimum height for surface courses on permeable pavement.

\begin{tabular}{|c|c|c|c|c|}
\hline Surface course type & Load type & $\begin{array}{l}\text { Minimum } \\
\text { height }(\mathrm{mm})\end{array}$ & $\begin{array}{c}\text { Mechanical } \\
\text { strength } \\
\text { (MPa) }\end{array}$ & Test method \\
\hline \multirow{2}{*}{$\begin{array}{l}\text { Paving units (solid } \\
\text { concrete) }\end{array}$} & Pedestrian & 60.0 & \multirow{2}{*}{$\geq 35.0$} & \multirow{4}{*}{ ABNT NBR 9781} \\
\hline & Light traffic & 80.0 & & \\
\hline \multirow{2}{*}{$\begin{array}{c}\text { Paving units } \\
\text { (pervious concrete) }\end{array}$} & Pedestrian & 60.0 & \multirow{2}{*}{$\geq 20.0$} & \\
\hline & Light traffic & 80.0 & & \\
\hline \multirow{2}{*}{ Concrete slab } & Pedestrian & 60.0 & \multirow{2}{*}{$\geq 2.0$} & \multirow{2}{*}{ ABNT NBR 15805} \\
\hline & Light traffic & 80.0 & & \\
\hline \multirow{2}{*}{$\begin{array}{l}\text { Pervious concrete } \\
\text { cast in place }\end{array}$} & Pedestrian & 60.0 & $\geq 1.0$ & \multirow{2}{*}{ ABNT NBR 12142} \\
\hline & Light traffic & 100.0 & $\geq 2.0$ & \\
\hline
\end{tabular}

The pervious concrete cast in place should have the density measure on field (fresh concrete) according ABNT NBR 9823 - Concreto fresco - Determinação da massa específica, do rendimento e do teor de ar pelo método gravimétrico and on hardened concrete according ABNT NBR 9778 - Argamassa e concreto endurecidos - Determinação da absorção de água, índice de vazios e massa especifica and should present density above $1600 \mathrm{~kg} / \mathrm{m}^{3}$. Later the mechanical resistance is obtained by correlation with density.

\subsubsection{Visual and dimensional inspection on paving units or slabs}

The paving units or slabs should present uniform aspect, regular edges, right angles, free of shavings, defects, delamination or flaking. The minimum height should comprise Table 5 and be multiple of $20 \mathrm{~mm}$ with $\pm 3 \mathrm{~mm}$ of tolerance.

\subsubsection{Sampling}

A pavement lot correspond to $2500 \mathrm{~m}^{2}$ of pavement area and each lot should be test according Table 6 . A specimen should be add for each $300 \mathrm{~m}^{2}$ of pavement until the $10.000 \mathrm{~m}^{2}$ limit.

Table 6: Minimum sampling on field.

\begin{tabular}{|l|l|c|c|}
\hline \multirow{2}{*}{ Type of surface } & Feature & \multicolumn{2}{|c|}{$\begin{array}{c}\text { Minimum specimens for } \\
2500 \mathrm{~m}^{2} \mathrm{lot}\end{array}$} \\
\cline { 3 - 4 } & & $\begin{array}{c}\text { Number of } \\
\text { specimens }\end{array}$ & Counterproof \\
\hline \multirow{2}{*}{$\begin{array}{l}\text { Paving units or } \\
\text { slabs }\end{array}$} & Visual inspection & 6 & 6 \\
\cline { 2 - 4 } & Dimensional avaliation & 6 & 6 \\
\cline { 2 - 4 } & Mechanical resistance & 6 & 6 \\
\hline \multirow{2}{*}{$\begin{array}{l}\text { Pervious } \\
\text { concrete cast in } \\
\text { place }\end{array}$} & Fresh concrete density & \multicolumn{2}{|c|}{ One for each15 $\mathrm{m}^{3}$} \\
\cline { 2 - 4 } & Hardened concrete density & 3 & 3 \\
\hline Both & Infiltration rate & 3 & 3 \\
\hline
\end{tabular}




\subsubsection{Hydraulic requirements}

For all surface types adopted the ABNT [2] specifies a minimum infiltration rate higher than $10^{-3} \mathrm{~m} / \mathrm{s}$. A constant head permeameter can be used to verify this requirement in case of pervious concrete while enlarged joints or open space paving units can be verify according to Equation 1, which normally corresponds between $7 \%$ and $15 \%$ of the total area, as seen in Figure 2.

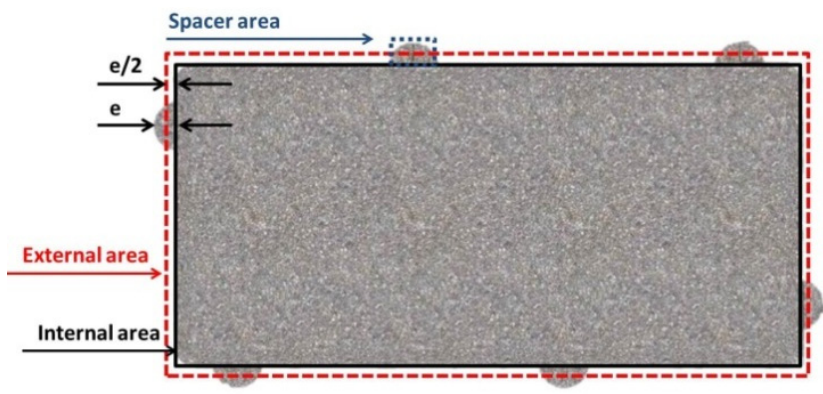

Figure 2: Area verification for enlarged joints or open space paving units.

The total percolation area should be obtained according equation (1):

$$
A_{\text {percolation }}=\frac{\text { external area }-(\text { internal area }+ \text { spacer } \text { area })}{\text { external area }} .
$$

\section{Construction}

The ABNT [2] does not bring specific guidelines on construction and only mentions that the chosen method should be in accordance with the surface course type and that the same procedure could be adopted as in the conventional pavement as long as it doesn't conflict with the requirements already mentioned. It was not the scope of the standard to provide detailed guidelines on construction but permeable pavement could require a few different methods from the conventional pavement that if not followed could damage the performance of the pavement.

\section{Maintenance and cleaning}

Maintenance is advised when the pavements present a runoff coefficient lower than $10^{-5} \mathrm{~m} / \mathrm{s}$ measured with the single ring method, described in section 9 . Maintenance consists of the following steps: sweeping, water jet, suction debris and replacement of grouting material, if applicable. After these procedures the runoff coefficient must be at least $80 \%$ of the minimum permeability coefficient, if not other maintenance actions should be implemented according to the surface type.

ABNT [2] points out that any repair should use the same material as in the existing pavement, and it is forbidden to use any material that highlights the repair 
or damages the pavement behavior. Often a repair in permeable pavement is made using conventional materials, normally because of lack of information of the user.

\section{Hydrological evaluation}

One of the main goals on ABNT [2] was to present a simple method of hydraulic evaluation in order to confirm the performance of the pavement. The ABNT [2] mention laboratory evaluation considering only the surface course and in place measure for the finish pavement (Table 7).

Table 7: Infiltration rate requirements.

\begin{tabular}{|c|c|c|c|}
\hline \multirow{2}{*}{ Surface course } & \multicolumn{2}{|c|}{ Test method } & $\begin{array}{l}\text { Infiltration } \\
\text { rate }(\mathrm{m} / \mathrm{s})\end{array}$ \\
\hline & Laboratory & In place & \\
\hline $\begin{array}{l}\text { Paving unit (enlarged } \\
\text { joints or open spaces) }\end{array}$ & $\begin{array}{l}\text { Single ring } \\
\text { method }\end{array}$ & \multirow{4}{*}{$\begin{array}{l}\text { Single ring } \\
\text { method }\end{array}$} & \multirow{4}{*}{$>10^{-3} \mathrm{~m} / \mathrm{s}$} \\
\hline $\begin{array}{l}\text { Pervious concrete } \\
\text { paving unit }\end{array}$ & \multirow{3}{*}{$\begin{array}{c}\text { Constant head } \\
\text { permeameter } \\
\text { ABNT NBR } \\
13292\end{array}$} & & \\
\hline Pervious concrete slab & & & \\
\hline $\begin{array}{l}\text { Pervious concrete cast } \\
\text { in place }\end{array}$ & & & \\
\hline
\end{tabular}

In the laboratory, the measurement is made using a constant head permeameter and the test method described in the soil standard ABNT NBR 13292 - Solo Determinação do coeficiente de permeabilidade de solos granulares à carga constante - Metodo de ensaio.

For in place measurement, the ABNT [2] brings as an attachment the single ring test method using as reference the ASTM [7]. This test method was initially proposed by Bean et al. [6] by adjusting a soil test method for permeable pavements. The method has been reviewed by Smith et al. [8] and Li et al. [9], who also analyzed the test method by the National Center for Asphalt Technology (NCAT). They both attested to the effectiveness of the ASTM [7] test method. The test method was successfully applied on field tests by Borst [10], Marchioni and Silva [5] and Jabur [11], confirming its simple operation and accurate results. It consists of pouring a pre-defined volume of water into a $30 \mathrm{~cm}$ cylinder maintaining a defined head measuring the time from when the water touches the pavement to full infiltration. The infiltration rate is then determined using an adaptation on Darcy's Law (Marchioni and Silva [5]).

The pavement acceptance relies on in place measurement, while the laboratory methods for surface course using pervious concrete are used only for preliminary acceptance. 


\section{Base and subbase hydrological design}

As an informative attachment the ABNT [2] brings a recommendation for the hydraulic design of the base and subbase based on BSI [1] and Smith [12]. The first step is defined by the infiltration type according to Table 8 .

Table 8: Infiltration type according to local features.

\begin{tabular}{|l|c|c|c|c|}
\hline \multicolumn{2}{|c|}{ Local conditions } & $\begin{array}{c}\text { Total } \\
\text { infiltration }\end{array}$ & $\begin{array}{c}\text { Partial } \\
\text { infiltration }\end{array}$ & $\begin{array}{c}\text { No } \\
\text { infiltration }\end{array}$ \\
\hline $\begin{array}{l}\text { Subgrade infiltration } \\
\text { rate } \mathrm{k}(\mathrm{m} / \mathrm{s})\end{array}$ & $>10^{-3}$ & & & \\
\cline { 2 - 5 } & $10^{-3} \mathrm{a} 10^{-5}$ & $\mathrm{x}$ & & \\
\cline { 2 - 5 } & $10^{-5} \mathrm{a} 10^{-7}$ & $\mathrm{x}$ & $\mathrm{x}$ & \\
\hline $\begin{array}{l}\text { Maximum water table level at least } \\
1 \mathrm{~m} \text { below the base }\end{array}$ & $\mathrm{x}$ & $\mathrm{x}$ & \\
\hline Contaminants presence & $\mathrm{x}$ & $\mathrm{x}$ & \\
\hline
\end{tabular}

The base depth is obtained according to the methodology mentioned in Smith [12] using equation (2). This depth refers only to the reservoir capacity of the base and does not exclude a mechanical design.

$$
d p=\frac{\Delta \boldsymbol{Q}_{c} \boldsymbol{R}+\boldsymbol{P}-\boldsymbol{f} \boldsymbol{T}_{\boldsymbol{e}}}{\boldsymbol{V}_{\boldsymbol{r}}}
$$

where: $\mathrm{dp}=$ depth of crushed stone base $(\mathrm{m}) ; \Delta \mathrm{Qc}=$ increased runoff from contributing area per given design storm $(\mathrm{m}) ; \mathrm{Ac}=$ contributing area $\left(\mathrm{m}^{2}\right) ; \mathrm{Ap}=$ pavement surface area $\left(\mathrm{m}^{2}\right) ; \mathrm{R}=$ contribution area and surface area ratio (Ac/Ap); $\mathrm{P}=$ design storm rainfall depth $(\mathrm{m}) ; \mathrm{f}=$ soil infiltration rate $(\mathrm{m} / \mathrm{h}) ; \mathrm{Te}=$ effective filling time of the base, typically 2 hours $(\mathrm{h}) ; \mathrm{Vr}=$ void ratio of the base crushed stone.

The infiltration rate (f) can be obtained according the test methods on $A B N T$ NBR 13292:1995 Solo - Determinação do coeficiente de permeabilidade de solos granulares à carga constante - Metodo de ensaio and ABNT NBR 14545:2000 Solo - Determinação do coeficiente de permeabilidade de solos argilosos a carga variável. The design storm rainfall depth $(\mathrm{P})$ should be obtained with data from local IDF (Intensity-duration-frequency) equation data considering a return period of minimum 10 years and $1 \mathrm{~h}$ duration.

\section{Conclusion}

The ABNT [2] will be published in 2015 and is expected to reach the interest stakeholders being municipalities, developers and contractors helping to guarantee acceptance performance on permeable pavement and reduction on pathologies. As is common in standards the text doesn't go further on details but provides the most important requirements for an acceptable performance of the pavement. However, it is still necessary for the development of specific guidelines for each type of surface course and cross section respecting the requirements mention on ABNT [2]. 


\section{References}

[1] BSI, Pavements constructed with clay, natural stone or concrete pavers. Guide for the design of permeable pavements constructed with concrete paving blocks and flags, natural stone slabs and setts and clay pavers. 2009.

[2] ABNT, $1^{\circ}$ PROJETO 18:600.10: Pavimentos permeáveis de concreto. 2013.

[3] Pagotto, C., M. Legret, and P. Le Cloirec, Comparison of the hydraulic behaviour and the quality of highway runoff water according to the type of pavement. Water Research, 2000. 34(18): pp. 4446-4454.

[4] Terzaghi, K. and R.B. Peck, Soil Mechanics in Engineering Practice: $2 d$ Ed. 1968: J. Wiley.

[5] Marchioni, M.L. and C.O. Silva. Método de ensaio para avaliação de pavimento permeável executado. in 55o Congresso Brasileiro do Concreto $C B C 2013$. 2013. Gramado: IBRACON.

[6] Bean, E.Z., et al., Study on the surface infiltration rate of permeable pavements. Proceedings of the American Society of Civil Engineers and EWRI 2004 world water and environmental resources congress, Salt Lake City, UT, USA, 2004. 27.

[7] ASTM, Standard Test Method for Infiltration Rate of In Place Pervious Concrete. 2009.

[8] Smith, D.R., K. Earley, and J.P.E. Lia. Potential application of ASTM C1701 for evaluating surface infiltration of permeable interlocking concrete pavements. in 10th International Conference on Concrete Block Paving. 2012. Shanghai.

[9] Li, H., M. Kayhanian, and J.T. Harvey, Comparative field permeability measurement of permeable pavements using ASTM C1701 and NCAT permeameter methods. Journal of Environmental Management, 2013. 118(0): pp. 144-152.

[10] Borst, M., Surface infiltration rates of permeable surfaces: Six month update (November 2009 through April 2010). 2010: National Risk Management Research Laboratory, Water Supply and Water Resources Division, US Environmental Protection Agency.

[11] Jabur, A.S., Relatório final de pós-doutorado 2013, Universidade Federal do Rio Grande do Sul. p. 42.

[12] Smith, D., Permeable Interlocking Concrete Pavements: Selection, Design, Construction, Maintenance. 2006: Interlocking Concrete Pavement Institute. 